\title{
A STUDY OF PARALYTIC TOXINS IN CULTURED MUSSELS FROM BULGARIAN BLACK SEA
}

\author{
G. Kalinova*, P. Mechkarova, M. Marinova
}

\author{
National Diagnostic and Research Veterinary Medical Institute, Sofia, Bulgaria
}

\begin{abstract}
Paralytic Shellfish Poisoning (PSP) in humans has not been reported in the region of Black Sea, but there are data for the presence of PSP produced dinoflagellates, as Alexandrium monilatum, Alexandrium ostenfeldii, Prorocentrum minimum, Gymnodinium species and etc. They may cause paralysis and death in consumers of contaminated shellfish. The aim of the study was to examine the contents of paralytic toxins in cultured mussels from the Bulgarian Black Sea coast. The analysed samples were from live mussels (Mitilus Galloprovincialis), breeding in 23 farms. To identify and to determine quantitatively individual PSP toxins was introduced chromatographic HPLC-FLD method. We found that 5 samples are contaminated with saxitoxin, decarbamoil goniotoxin 2,3 and traces of goniotoxin -5 within the range of $(89.3$ - 428.7) $\mu \mathrm{g}$ STX.2HCL equivalent $/ \mathrm{kg}$. The quantities of PSP toxins in all positive samples were below the health standard of $800 \mu \mathrm{g}$ STX.2HCL equivalent $/ \mathrm{kg}$. The toxicity profile of tested samples is a typical for producer of genus Alexandrium spp. This was the first study of paralytic toxins in cultured mussels, farmed in the Bulgarian Black Sea coast. Taking into account the results obtained, it can be concluded that the level of contamination of paralytic toxins in the Bulgarian part of Black Sea is a minimal.
\end{abstract}

Key words: paralytic toxins, cultured mussels, phytoplankton in Black Sea

\section{INTRODUCTION}

Recent years, the rearing of aquaculture from mussels in Bulgaria is growing rapidly. According to the Bulgarian Food Safety Agency near the Bulgarian Black Sea coast are registered 25 mussel farms. In the northern part of the sea, they are located in the region of Kavarna and Varna, in the southern - close to Nesseber, Ravda, Burgas, Chernomorec, Primorsko, Duni and Sozopol.

The average annual production of mussels is over 30,000 tons.

Mussels are bivalve molluscs filter-feeding in which tissue are accumulated different toxic substances including marine biotoxins. The presence of biotoxins in shellfish can cause serious health problems for consumers. The most dangerous spread are paralitic shellfish poisonings (PSP), which, in extreme cases, can lead to death due to respiratory distress and

\footnotetext{
*Correspondence to: Ginka Kalinova, 1606-Sofia, "Pencho Slaveikov" blvd. 15, NDRVMI Tel.: +359 885728182, Fax: +359295253 06, E-mail:

kakalinova@yahoo.com
}

muscle paralysis. The clinical picture of poisoning develops from 2 to 24 hours after eating contaminated mussels. PSP toxins are a common cause for poisoning in Europe, North America, Japan, South Africa, Australia, India, New Zealand, Thailand, the Philippines and Papua New Guinea (1).

Marine biotoxins are produced by microscopic algae (dinoflagellates). Under certain conditions - climate, salinity and temperature of the water, household and industrial waste, etc.- the toxic algae increas on the surface of the seawater. This phenomenon is known as "blooming" or "red tide" because of the change in the color of the water.

The occurrence of phytotoxic species, producing paralytic toxins in Black sea The development of phytoplankton in Black Sea has been studied for more than a century. 544 species of phytoplankton found in the Bulgarian section of Black Sea have been described for the period $1980-2005$ (2-5).

In the list of established species phytoplankton in Black Sea that produce paralytic toxins are 
Alexandrium spp., Gymnodinium spp., Prorocentrum spp. (6).

During the period 1980-1990, have been conducted seasonal studies (spring and autumn) of dominant phytoplankton complexes in the coastal water area of a polygon Galata for the presence of Alexandrium monilatum and Lingulodinium polyedrum, associated with an initial assessment of the state of the marine environment (7).

In the waters of the Cape Kaliakra and Cape Galata has seen "blooms" of algae with unusual composition during the autumn of 2003. The dinoflagellates of the types Gymnodinium sp., Prorocentrum minimum and Alexandrium monilatum, that prevailed and the biomass has been more than $15 \mathrm{~g} / \mathrm{m}^{3}$ (2).

Vershinin and Moruchkov (8) have discovered algae of the genus Alexandrium spp. in the Caucasian coast of the Black Sea in the summer of 2001. After a period of storms and rains, that caused the resuspension of sediments, has seen massive development of this type in concentrations up to 4500 cells $/ 1$ in July 2001 and winter of 2002.
For the period 1991 - 20015 cases of "blooms" of red algae along Eastern Black Sea Coast of Turkey were reported (9). Studies have shown that the "bloom" has been a result of the development of six types of phytoplankton, including toxic Gymnodinium sanguineum.

PSP toxins - physicochemical properties, classification and toxicity

The most famous member of the group of paralytic toxins is saxitoxin (STX). Narahashi (10) has found that saxitoxin is 1000 times more toxic than sodium cyanide, since $\mathrm{LD}_{50}$ of saxitoxin is $10 \mu \mathrm{g} / \mathrm{kg}$, and for sodium cyanide $\mathrm{LD}_{50}$ is $10 \mathrm{mg} / \mathrm{kg}$. Saxitoxin has been placed on the list of the Chemical Weapons Convention together with ricin.

Paralytic toxins are stable at acidic $\mathrm{pH}$ and when heated, do not impart odor and taste to the food. High temperature cooking or freezing of mussels does not lead to the elimination of toxins.

In a recent review of Wiese et al. (11) 57 analogues of saxitoxin are described. Paralytic toxins are hydrophilic and are classified into three structural subgroups - Table 1 (12):

Table 1. Classification of PSP toxins into three structural subgroups

\begin{tabular}{|l|l|l|}
\hline $\begin{array}{l}\text { Carbamoyl } \\
\text { Saxitoxins }\end{array}$ & $\begin{array}{l}\text { Decarbamoyl } \\
\text { Saxitoxins }\end{array}$ & $\begin{array}{l}\text { N-sulfocarbamoyl } \\
\text { Saxitoxins }\end{array}$ \\
\hline Saxitoxin (STX) & dcSTX & Gonyautoxin 5 (GTX-5) \\
\hline Neosaxitoxin (NEO) & dc-NEO & Gonyautoxin 6 (GTX-6) \\
\hline $\begin{array}{l}\text { Gonyautoxins (GTXs) } \\
(\text { GTX1, 2, 3, 4) }\end{array}$ & $\begin{array}{l}\text { dc-GTXs } \\
(\text { dc-GTX1, } 2,3,4)\end{array}$ & $\begin{array}{l}\text { N-sulfocarbamoylgonyautoxin } \\
\text { Cs }(C 1,2,3,4)\end{array}$ \\
\hline
\end{tabular}

In order to take into account the toxicity of saxitoxin analogues, European Food Safety Agency (EFSA) recommended toxic equivalency factors (TEFs), (13). Using these factors, the toxicity of PSP toxins is expressed as $\mu \mathrm{g}$ STX.2HCL equivalent $/ \mathrm{kg}$, since 2009 year. The most toxic analogues are neosaxitoxin (NEO), goniotoxin 1 (GTX1) and decarbamoilsaxitoxin (dc-STX), which have the same effect of toxicity as saxitoxin $(\mathrm{TEFs}=1)$.

Legislation:

Regulation (EU) №853 / 2004, Annex III, Section V introduced specific requirements for growing and harvesting of bivalve molluscs (14). The health standards are set for maximum levels of marine biotoxins in bivalve molluscs:

- Manufacturers must ensure that live bivalve molluscs on the market meet the health standards;
- The amount of a paralytic toxins should not exceed 800 micrograms per kilogram.

Under the provisions of Regulation (EU) № 854/2004, Annex II, Chapter, II, point B: "The sampling frequency for toxin analysis in the molluscs is, as a general rule, to be weekly during the periods at which harvesting is allowed". This frequency can be changed (increased or decreased) for a certain area or type of bivalve molluscs, depending on the analysis of the risk of toxins or phytoplankton (15).

The aim of this study was to examine cultured mussels from the Bulgarian Black Sea coast for a content of paralytic toxins, applying HPLC method with fluorescence detection (16). Together with this to identify the type of 
paralytic toxins and try to find a relation to the type of phytoplankton causes these toxins.

\section{MATERIALS AND METHOD}

Origin of the samples and sample preparation All analyzed samples (57 pieces) were alive mussels, cultivated in 23 farms on the Bulgarian coast. The mussels were from the genus Mitilus Galloprovincialis. The samples were obtained at the NRL 'Marine biotoxins' from official control and monitoring of farms for the period 2010 - 2014. Samples were received throughout the years above.

\section{Method}

The analysis was done according AOAC OMA 2005.6 (16).

All reagents used were of HPLC or analytical grade and all solutions were prepared in deionized water.

Chromatographic conditions and equipment
KALINOVA GA., et al.

HPLC analysis was performed using UltiMate 3000 Thermo Fisher Scientific Dionex, equipped with quaternary pump UltiMate 3000 Pump, vacuum degazer, autosampler, injector, fluorescent detector Dionex RF 2000; chromatographic column Kinetex: C18, 150 $\mathrm{mm} \times 4.6 \mathrm{~mm}, 5 \mu \mathrm{m}$ particle size; flow rate of the mobile phase $1 \mathrm{ml} / \mathrm{min}$.

Calibration curves

PSP toxin profile was identified by comparing chromatograms of certified standard materials (dc-GTX2,3; C1,2, dc-STX, GTX2,3; GTX5, STX, NEO, GTX1,4 and dc-NEO) delivered by NRC, Halifax, Canada. The concentration of each PSP toxin in the samples was determined by means of calibration graphs with five concentration levels. Figure 1 provides an chromatogram of 9 certified standard materials after periodate oxidation.

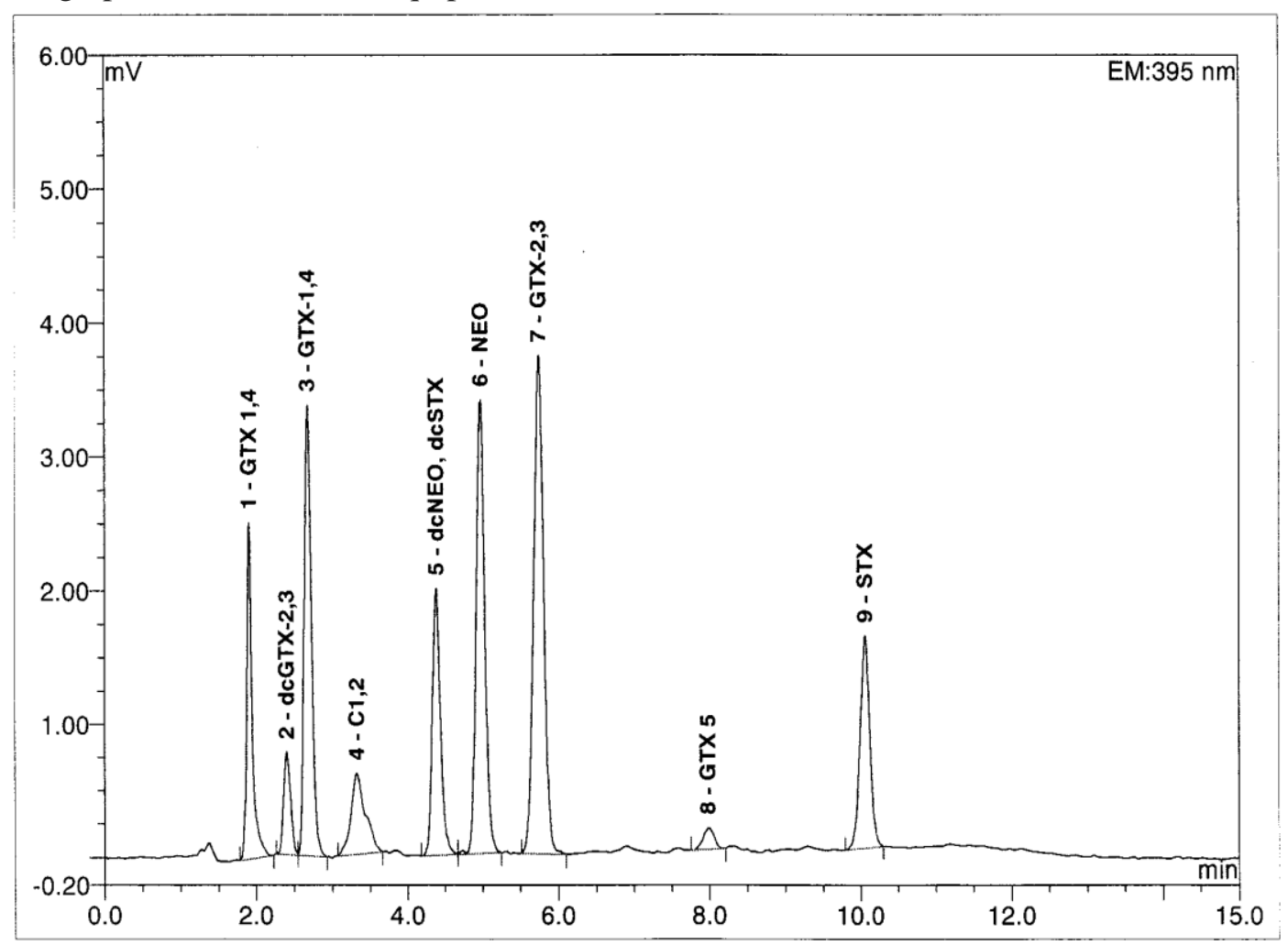

Figure 1. A chromatogram with 9 paralytic toxins (certified reference materials), obtained after periodate oxidation

The limits of quantitation (LOQ) of the nine toxins were in range of $(20-89.3) \mu \mathrm{g}$ STX.2HCL equivalent $/ \mathrm{kg}$.

The linearity of nine calibration graphs ( $r>$ 0.99) were for the concentrations in range of $(20$ - 800) $\mu \mathrm{g}$ STX.2HCL equivalent $/ \mathrm{kg}$. The total amount of paralytic toxins was presented as $\mu \mathrm{g}$ STX dihydrochloride equivalent $/ \mathrm{kg}$.

\section{RESULTS AND DISCUTIONS}

The results for the content of paralytic toxins in positive samples are presented in Table 2.

It was noted that only 5 from all 57 samples were positive for paralytic toxins. The sample with the greatest amount of paralytic toxins was № 374 from June 2011, from the northern coast - farm № 3. Figure 2 presents the chromatogram obtained after peroxide oxidation of sample № 374 . 
KALINOVA GA., et al.

Table 2. The established content of paralytic toxins in cultured mussels from Bulgarian Black Sea coast for the period 2010-2014

\begin{tabular}{|c|c|c|c|c|c|c|c|}
\hline \multirow{3}{*}{ № } & \multirow{3}{*}{ № sample } & \multirow{3}{*}{ № Farm } & \multirow{3}{*}{ Period } & \multicolumn{4}{|c|}{ Results - $\mu$ g STX.2HCL equivalent $/ \mathrm{kg}$} \\
\hline & & & & & & & \\
\hline & & & & STX & dc-GTX2,3 & GTX 5 & $\begin{array}{l}\text { Total } \\
\text { toxicity }\end{array}$ \\
\hline 1. & 374 & $\begin{array}{l}\text { № } 3 \text { - } \\
\text { northern coast }\end{array}$ & June, 2011 & 428.7 & traces & traces & 428.7 \\
\hline 2. & 12 & $\begin{array}{l}\text { № } 10- \\
\text { southern coast }\end{array}$ & January, 2012 & - & 227.8 & - & 227.8 \\
\hline 3. & 282 & $\begin{array}{l}\text { № } 8 \text { - } \\
\text { southern coast }\end{array}$ & March, 2012 & 89.3 & traces & - & 89.3 \\
\hline 4. & 785 & $\begin{array}{l}\text { № } 8 \text { - } \\
\text { southern coast }\end{array}$ & August, 2012 & - & 145.3 & - & 145.3 \\
\hline 5. & 786 & $\begin{array}{l}\text { № } 5 \text { - } \\
\text { northern coast }\end{array}$ & August, 2012 & - & 144.1 & - & 144.1 \\
\hline
\end{tabular}

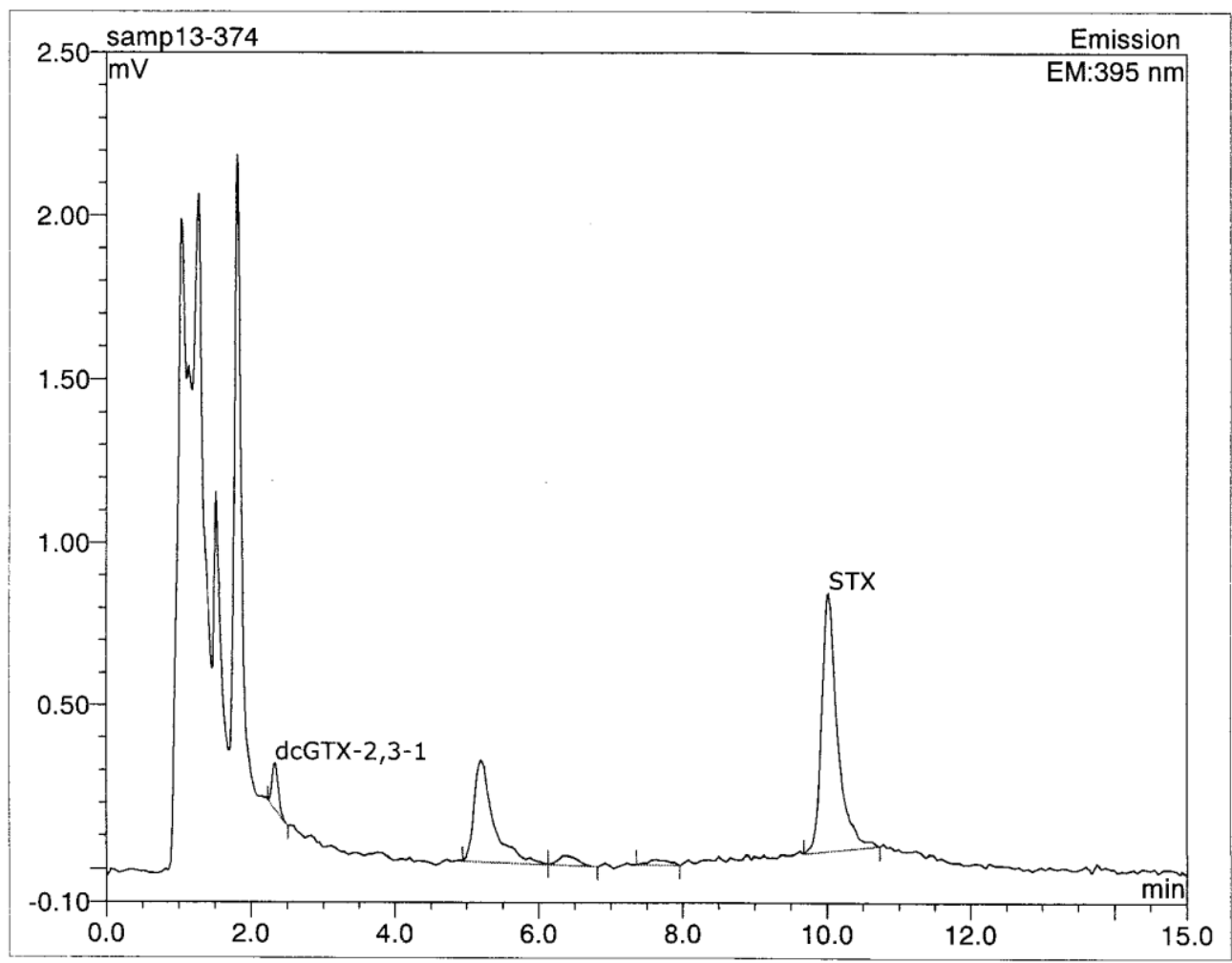

Figure 2. A chromatogram of sample № 374 from 2011year, from the north coast, obtained after peroxide oxidation.

This sample consisted $428.7 \mu \mathrm{g}$ STX.2HCL equivalent $/ \mathrm{kg}$ saxitoxin (STX) and traces of goniotoxin 2,3 (GTX 2,3). During next months of 2011 there were no samples of this water area and toxicity was not investigated.

Most samples with a presence of paralytic toxin were in 2012. In a sample from farm №
8 from the southern coast in March 2012 were identified two PSP toxins - saxitoxin (STX) with the amount of $89.3 \mu \mathrm{g}$ STX.2HCL equivalent $/ \mathrm{kg}$ and decarbamoil goniotoxin 2,3 (dc GTX 2,3) in traces. In August a test sample from the same farm № 8 was positive again, but it was contained only decarbamoil goniotoxin 2,3 (dc GTX 2,3) with amount of 
$145.3 \mu \mathrm{g}$ STX.2HCL equivalent $/ \mathrm{kg}$. In the other two positive samples in 2012 were detected only decarbamoil goniotoxin 2,3 (dc GTX 2,3) with amount of 227.8 and $144.1 \mu \mathrm{g}$ STX.2HCL equivalent $/ \mathrm{kg}$. The samples were from farms in northern and southern coast.
KALINOVA GA., et al. The samples from 2013 and 2014 year did not contain PSP toxins.

The toxicity of the five positive samples was below the health standard of $800 \mu \mathrm{g}$ STX.2HCL equivalent $/ \mathrm{kg}$, referred to in European legislation (Figure 3).

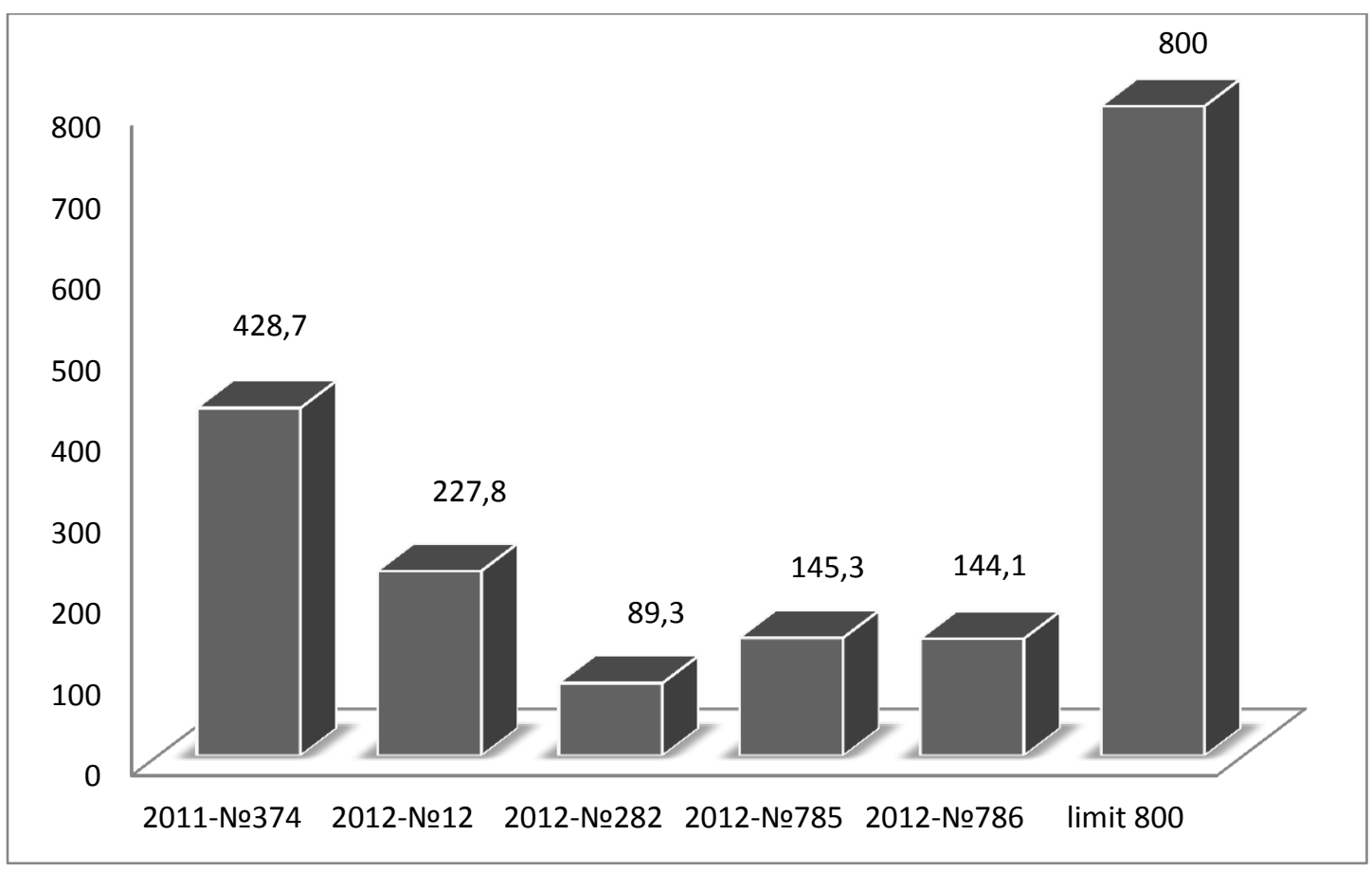

Figure 3. A quantity of paralytic toxins determined in cultured mussels from Bulgarian Black Sea coast for the period 2010-2014, compared with the limit for PSP toxins - $800 \mu \mathrm{g}$ STX.2HCL equivalent $/ \mathrm{kg}$.

The results shown that the toxicity profile of positive samples was from saxitoxin (STX), decarbamoil goniotoxin 2,3 (dc GTX 2,3) and traces of goniotoxin 5 (GTX 5). As a typical producer of the identified toxins in the positive samples could be determined the genus Alexandrium spp.

A confirmation of this conclusion were the results of Vershinin and colleagues (17). They have identified the type of algae Alexandrium spp. during a monitoring of the northeast coast of the Black Sea in the period 2001-2004, with the highest density of the cells in August 2004. The authors have determined the exact type of dinoflagellates with a scanning electron microscope and have found Alexandrium tamarense and Alexandrium minutum. Within the monitoring they explored extracts from hepatopancreas of mussels for content of PSP toxins with the method we used - HPLC and fluorescence detection - and established saxitoxin (STX), goniotoxin 2,3 (GTX2,3) and goniotoxin 5 (GTX5).

As an disadvantage of the official control could be reported that the samples for analysis were sent only once a year and so the authors had no data on contamination in the remaining months. In order to assess the toxicity of hydrobionts was necessary to respect the requirements of EU Regulation 854/2004: The sampling frequency for toxin analysis in the molluscs to be once per week during the periods in which harvesting is allowed.

\section{CONCLUSION}

This was the first study of paralytic toxins in cultured mussels, farmed in the Bulgarian Black Sea coast. The quantities of PSP toxins were below the health standard of $800 \mu \mathrm{g}$ STX.2HCL equivalent $/ \mathrm{kg}$.

By using HPLC method with fluorescence detection were identified the type of individual paralytic toxins in the tested samples and was proven the relationship with types of algae producing them.

When the control of bivalve molluscs intended for human consumption is carried out once per year cannot guarantee that they meet the health standards laid down in European legislation. It is necessary to reinforce the control of cultured 
Black Sea mussels, offered on the Bulgarian consumer.

Taking into account the results obtained, it can be concluded that the level of contamination of paralytic toxins in the Bulgarian section of the Black Sea is minimal.

\section{REFERENCES}

1. Hallegraeff, G.M., A review of harmful algal blooms and their apparent global increase. Phycologia, 32:79-99, 1993.

2. BSC, State of the Environment of the Black Sea (2001 - 2006/7). Edited by Temel Oguz. Publications of the Commission on the Protection of the Black Sea Against Pollution (BSC) 20083, Istanbul, Turkey, Chapter 5 - State of Phytoplankton, 2008.

3. Velikova, V., Moncheva, S., Petrova, D., Phytoplankton dynamics and red tides (1987-1997) in the Bulgarian Black Sea. Water Sci. Technol. 39: 27-36, 1999.

4. Moncheva S., Kamburska, L., Plankton stowaways in the Black Sea- impacts on biodiversity and ecosystem health. In: Alien marine organisms introduced by ships in the Mediterranean and Black Seas, CIESM Workshop Monographs, Monaco, 20: 47-53, 2002.

5. Moncheva S., Phytoplankton Shifts in the Black Sea - Driving Forces and Possible Implication for Reference Conditions. Joint Workshop on Streamlining the Process of Producing Regional Assessments on Eutrophication for PanEuropean Purposes, 2005.

6. http://phyto.bss.ibss.org.ua/wiki/List_chec ked

7. Тодорова В., Мончева С., Първоначална оценка на състоянието на морската околна среда, съгласно чл. 8 от НООСМВ, 2013.

8. Вершинин А.О., Моручков А. А., Потенциально - токсичные водоросли в прибрежном фитопланктоне северовосточной части Чёрного моря. Экология моря, Вып. 64, 2003.
KALINOVA GA., et al.

9. Feyzioglu A. M., Ogut H., Red Tide Observations along the Eastern Black Sea Coast of Turkey. Turk J Bot., 30, 2006.

10. Narahashi T. Mechanism of tetrodotoxin and saxitoxin action. Marine Toxins and Venoms, 3:185-210,1998.

11. Wiese, M., D'Agostino, P. M., Mihali, T. K., Moffitt, M. C., Neilan, B.A., Neurotoxic alkaloids: saxitoxin and its analogs. Mar. Drugs, 8:2185-2211, 2010.

12. Oshima, Y. Postcolumn derivatization liquid chromatographic method for paralytic shellfish toxins. J. AOAC. Int., 78:528-532, 1995.

13. Scientific Opinion of the Panel of Contaminants in the Food Chain on a request from the European Commission on Marine Biotoxins in Shellfish Saxitoxin Group. The EFSA Journal. 1019: 1-76, 2009.

14. Regulation (EC) No 853/2004 of the European parliament and of the council of 29 April 2004 laying down specific hygiene rules for on the hygiene of foodstuffs. Off. J. Eur. Union L139, 55205, 2004.

15. Regulation (EC) No 854/2004 of the European parliament and of the council of 29 April 2004 laying down specific rules for the organisation of official controls on products of animal origin intended for human consumption, 2004.

16. Official Methods of Analysis of the Association of Official Analytical Chemists. 2005. Method 2005.06: Paralytic Shellfish Poisoning Toxins in Shellfish. Prechromatographic Oxidation and Liquid Chromatography with Fluorescence Detection (First Action 2005). AOAC INTERNATIONAL, Gaithersburg, MD, U.S.A. 18th Ed.: pp. 83-96, 2006.

17. Vershinin, A. O., Morton, S., Leighfield, T., Alexandrium in the Black SeaIdentity, Ecology and PSP Toxicity. African Journal of Marine Science, 28: pp. 209-213, 2006. 